\title{
Neuroprotective Effect of Paeonol in the Rat Model of Traumatic Brain Injury
}

\author{
Rat Travmatik Beyin Hasarı Modelinde Paeonol'ün Nöroprotektif Etkisi
}

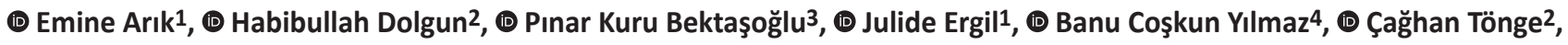 \\ (1) Özden Çağlar Öztürk ${ }^{3}$, (1) Levent Gürses ${ }^{2}$, (1) Bora Gürer ${ }^{3}$ \\ 1 University of Health Sciences Turkey, Dışkapı Education and Research Hospital, Clinic of Anaesthesiology and Reanimation, Ankara, Turkey \\ 2University of Health Sciences Turkey, Dışkapı Education and Research Hospital, Clinic of Neurosurgery, Ankara, Turkey. \\ 3 University of Health Sciences Turkey, Fatih Sultan Mehmet Education and Research Hospital, Clinic of Neurosurgery, istanbul, Turkey \\ ${ }^{4}$ Mersin University School of Medicine, Department of Histology and Embryology, Mersin, Turkey
}

\section{Abstract}

Objectives: Traumatic brain injury (TBI) is a major cause of disability and mortality that induces oxidative stress and apoptosis causing cellular damage. Several animal models have shown paeonol to be a powerful antioxidant, antiapoptotic, and neuroprotective substance. This study aimed to investigate possible neuroprotective effects of paeonol in a rat TBI model.

Materials and Methods: Thirty-two male rats were divided into four groups: control, trauma, vehicle, and paeonol groups. Trauma, vehicle, and paeonol groups were subjected to closed-head, contusive weight-drop injuries. The vehicle (saline) or paeonol (50 mg/kg) was orally administered as premedication for 15 days. Brain samples were obtained 24 hours after trauma. Histomorphological evaluation of the cerebral cortex was performed using electron and light microscopy.

Results: Histopathological examination revealed that the TBI-induced cerebral cortex damage was less in the paeonol group.

Conclusion: Paeonol exhibited neuroprotective and anti-edematous effects against TBI.

Key Words: Anti-edema, Neuroprotection, Paeonol, Traumatic Brain Injury

\section{$\ddot{0} z$}

Amaç: Travmatik beyin hasarı (TBH), oksidatif stres ve hücresel hasara neden olan apoptozu indükleyen temel bir sakatlık ve ölüm nedenidir. Bazı hayvan modelleri paeonolün güçlü bir antioksidan, antiapoptotik ve nöroprotektif madde olduğunu göstermiştir. Bu çalışma, paeonolün rat TB। modelinde olası nöroprotektif etkilerini araştırmayı amaçlamıştır.

Gereç ve Yöntemler: Otuz iki erkek rat dört gruba ayrıldı: kontrol, travma, taşıyıcı ve paeonol. Travma, taşıyıcı ve paeonol gruplarında kapalı kafa travması ağırlık düşürülerek uygulandı. Taşıyıcı (serum fizyolojik) veya paeonol $(50 \mathrm{mg} / \mathrm{kg}$ ) 15 gün boyunca premedikasyon olarak oral yoldan uygulandı. Beyin örnekleri travmadan 24 saat sonra alındı. Serebral korteksin histomorfolojik değerlendirmesi elektron ve ışık mikroskopisi kullanılarak yapıldı.

Bulgular: Histopatolojik incelemede, paeonol grubunda TBH kaynaklı serebral korteks hasarının daha az olduğu görüldü.

Sonuç: Paeonol, TBI'ya karşı nöroprotektif ve antiödematöz etkiler sergilemiştir.

Anahtar Kelimeler: Antiödem, Nöroproteksiyon, Paeonol, Travmatik Beyin Hasarı

Address for Correspondence/Yazışma Adresi: Dr. Pınar Kuru Bektaşoğlu, University of Health Sciences Turkey, Fatih Sultan Mehmet Education and Research Hospital, Clinic of Neurosurgery, İstanbul, Turkey

E-mail: pnr.kuru@gmail.com ORCID: orcid.org/0000-0001-9889-9955

Received/Geliş: 10.01.2020 Accepted/Kabul: 06.05.2020

๑Copyright 2020 Ankara University Faculty of Medicine

Journal of Ankara University Faculty of Medicine is published by Galenos Publishing House.

All content are under CC BY-NC-ND license. 


\section{Introduction}

Traumatic brain injury (TBI) is responsible for approximately one-third of injury-related mortality and is the leading cause of disability (1). The primary injury occurring during the trauma causes direct mechanical damage to the neuronal and surrounding supportive cells and vascular structures. The secondary injury occurs within minutes after trauma, resulting in further cell death because of several signaling cascades, such as oxidative stress, apoptosis, inflammation, ischemia, mitochondrial dysfunction, and neurotransmitter excitotoxicity $(2,3)$. Secondary injuries are preventable, although the cause of functional disability may require hours or years to resolve (4). The last decade witnessed research regarding several potential neuroprotective agents; however, none of these agents were approved for clinical use, except for amantadine sulfate $(3,5-$ 9). After TBI, the reactive oxygen species and pro-inflammatory cytokines are considered to play crucial roles $(7,10)$. Oxidative stress also induces apoptosis through increased caspase-3 activity $(9,11)$.

Paeonol (2'-hydroxy-4'-methoxyacetophenone) is a major phenolic component of the Chinese herbal medicines; Moutan Cortex of Paeonia suffruticosa Andrews and the root of Paeonia lactiflora Pall. Paeonol has been shown to exhibit antipyresis, antiapoptotic, anti-inflammatory, antiallergic, antimicrobial, antitumor, antidepressant, analgesic, and sedative properties $(12,13)$. In addition to the above-mentioned activities, paeonol has also been suggested to have properties of scavenging free radicals, antioxidation, and anti-platelet aggregation. Paeonol is proved to have activity in decreasing $\mathrm{Ca}^{2+}$ influx by blocking L-type $\mathrm{Ca}^{2+}$ channels (13). It prevents microglial activation and inhibits the activation of several inflammatory signaling pathways $(14,15)$. Furthermore, chronic treatment with paeonol inhibits endoplasmic reticulum stress-mediated oxidative stress (16).

Despite earlier studies on the neuroprotective activity of paeonol in animal models, its activity in TBI remains unexplored. The present study investigates the neuroprotective activity of paeonol in a rat model of TBI for the first time.

\section{Materials and Methods}

\section{Experimental Groups}

Animal care and all experiments were conducted according tothe European Parliament and Council directive 2010/63/EU of September 22, 2010 with regard to the protection of animals for experimental use. Animal ethics committee permission is obtained from The Saki Yenilli Animal Care and Use Committee (0001.01.02). They reviewed and approved all experimental procedures used in this study. Thirty-two adult male Wistar albino rats weighing 350-450 $\mathrm{g}$ were used. Animals were housed in an air-conditioned room with $12 \mathrm{~h}$ light and dark cycles with constant temperature $\left(22 \pm 2^{\circ} \mathrm{C}\right)$ and relative humidity (65-70\%). Rats were fed standard laboratory chow and had free access to water.

The rats were randomly assigned to the following four groups:

1. Control group ( $n=8)$ : Rats underwent only a skin incision. Non-traumatized brain samples were obtained $24 \mathrm{~h}$ after surgery. The brain divided into $1-\mathrm{mm}^{3}$ pieces and stored in glutaraldehyde for electron and light microscopic examination.

2. Trauma group $(n=8)$ : Rats underwent TBI as described below. Brain samples were obtained $24 \mathrm{~h}$ after surgery and were used for histopathological analysis.

3. Vehicle group $(n=8)$ : Rats underwent $T B I$ as described below and received a 15-day oral dose of the vehicle $(0.9 \%$ $\mathrm{NaCl}, 0.1 \mathrm{~mL} / 100 \mathrm{~g}$ ). Brain samples were removed $24 \mathrm{~h}$ after injury and were used for histopathological analysis.

4. Paeonol group ( $n=8)$ : Rats received a 15-day oral dose of paeonol (50 mg/kg; Sigma-Aldrich, St. Louis, Missouri, USA) as premedication before TBI. The chosen dose of paeonol was based on previous studies $(13,17)$. Brain samples were removed $24 \mathrm{~h}$ after TBI and were used for histopathological analysis.

\section{Anesthesia and Induction of TBI}

The animals were anesthetized using an intraperitoneal injection of $10-\mathrm{mg} / \mathrm{kg}$ xylazine (Rompun, Bayer, Turkey) and $50-\mathrm{mg} / \mathrm{kg}$ ketamine (Ketalar, Parke-Davis, Turkey) combination and allowed to breathe spontaneously. The moderate brain injury model described by Marmarouet al. (18) and modified by Ucar et al. (19) was applied for head trauma. The rats were placed in a prone position on the table and were supported on a $10-\mathrm{cm}$ foam bed to provide deceleration after the impact. A midline incision was created on the head, and the coronal and lambdoid sutures were identified. A metallic disk of $10-\mathrm{mm}$ diameter and 3-mm thickness was fixed to the cranium using bone wax between the two sutures in the midline. Trauma was applied at the point where the disk was placed on the midline. A lead object weighing $300 \mathrm{~g}$ was allowed to fall freely from a height of $1 \mathrm{~m}$ through a copper tube on to the metal disk over the skull of the rat. After the induction of injury, the metallic disk was removed, the surgical area was cleaned, and the skin was sutured. All the animals were decapitated 24 hours after trauma, and the brains were carefully removed.

\section{Sample Preparation for Electron and Light Microscopy}

For transmission electron microscopic evaluation, the brain tissue samples were fixed with $2.5 \%$ glutaraldehyde, postfixed with $1 \%$ osmium tetroxide, dehydrated in a graded alcohol 
series, cleared with propylene oxide, and embedded in Epon (EMS, Cat No: 13940).

Semi-thin sections $(2000 \mathrm{~nm})$ were cut using an ultramicrotome (Leica EM UC7, Leica Microsystems GmbH, Vienna, Austria) and stained with toluidine blue. These sections were examined using a light microscope (Olympus BX50) and photographed (Olympus LC30).

Thin sections $(70 \mathrm{~nm})$ were cut using an ultramicrotome and contrasted with uranyl acetate and lead citrate. These sections were examined and photographed usinga transmission electron microscope (JEOL JEM-1011, Jeol Ltd., Tokyo, Japan).

\section{Results}

\section{Electron Microscopic Findings}

The control group revealed normal morphological features of neuron and glial cells, myelin sheath, axon, and neuronal processes (Figure 1). On examination, the trauma group revealed significant perivascular edema, with remarkable intracellular edema and vacuoles observed in the neuronal processes adjacent to the oligodendrocytes. The axons and myelin sheath showed degenerative changes (Figure 2). Furthermore, the vehicle group revealed perivascular edema, with intracellular edema and vacuoles in neuronal processes (Figure 3). Myelin damage was observed in the paeonol group, although reduced perivascular edema was observed in the paeonol group compared with that in the trauma group. In addition, intracellular edema and vacuoles in the neuronal processes were decreased (Figure 4).

\section{Light Microscopic Evaluation}

Semi-thin sections belonging to study groups were examined and reduced perivascular edema was observed in the paeonol-

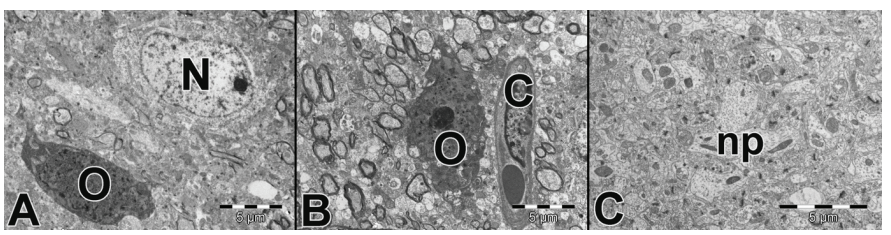

Figure 1: Electron microscopic image of control group. Normal morphological apperance of Neuron (N), Oligodendrocyte (0), Capillary (C), Neuronalprocesses (np). A and B X5000, C X7500

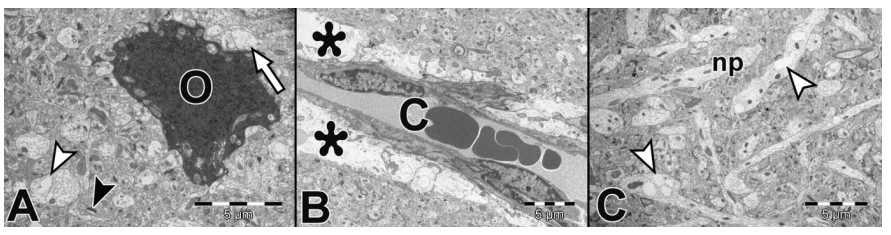

Figure 2: Electron microscopic image of trauma group. Capillary (C), intracellular vacuole in the neuronal processes (np) (white arrow head), intracellular edema and vacuoles in the adjacent to the oligodendrocyte (0) (white arrow), perivascular edema (asterisk), synapse (black arrow head). A X7500, B X4000, C X5000 treated group compared with that in the trauma and vehicle groups (Figure 5).

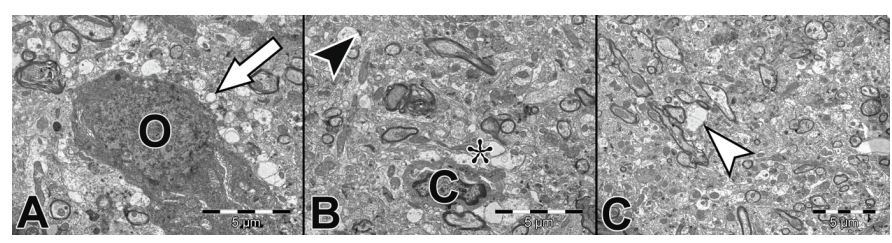

Figure 3: Electron microscopic image of vehicle group. Capillary (C), intracellular vacuole in the neuronal processes (white arrow head), intracellular edema and vacuoles in the adjacent to the oligodendrocyte (0) (white arrow), perivascular edema (asterisk), and synapse (black arrow head). A X7500, B X7500, C X5000

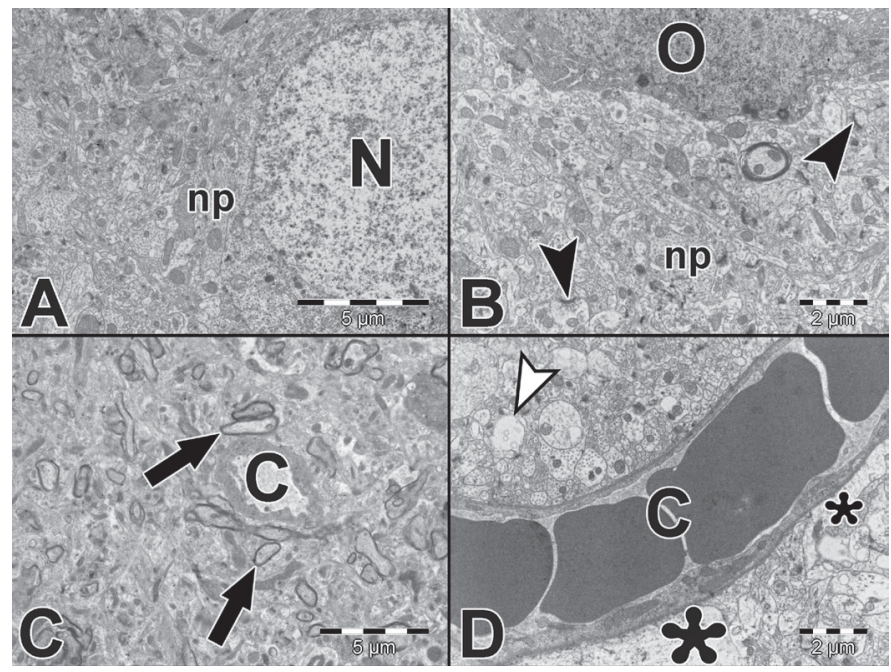

Figure 4: Electron microscopic image of paeonol group. Neuron (N), Oligodendrocyte (0), Capillary (C), intracellular vacuole in the neuronal processes (np) (white arrow head), myelin sheath (blackarrow) and synapse (black arrow head), perivascular edema (asterisk). A X7500, B X10000, C X6000, D X10000

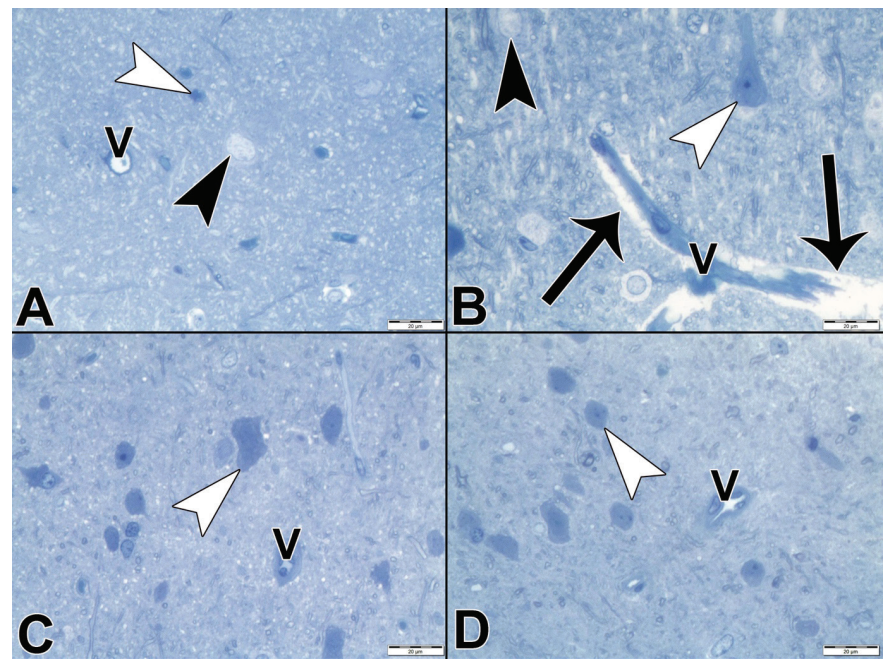

Figure 5: Light microscopic image, semithin sections. (A) Control group, (B) Trauma group, (C) Vehicle group, (D) Paeonol group. Neuron (black arrow head), glial cells (white arrow head), perivascular edema (black arrow), vessels (v). Toluidine blue, X400 


\section{Discussion}

TBI is one of the most significant causes of disability and mortality in young people worldwide (20). Secondary injury, after the initial mechanical injury during the incident, is triggered by oxidative stress, apoptosis, inflammation, excitotoxicity, ischemic processes, and mitochondrial pathways, resulting in neuronal loss (3). The last decade has witnessed decreased mortality rates and increased functional survival rates after TBI because of enhanced knowledge of TBI pathophysiology, improvement of intensive care services, technological developments in monitoring, and follow-up of patients (9). However, despite extensive research regarding neuroprotective agents, no clinically effective pharmacological treatment has been developed for TBI $(3,6,7,9,11)$. Consequently, TBI treatment has garnered interest and extensive research is underway to develop a possible therapeutic agent.

Paeonol is a major phenolic component of Moutan bark, the root bark of Paeoniasuffruticosa Andrews (Paeoniaceae) that is a traditional Chinese herbal medicine (21). It is known for its broad range of therapeutic properties probably because of its free radical scavenging and anti-inflammatory properties, including antiproliferative, antiplatelet aggregation, and neuroprotective activities $(22,23)$. It can cross the blood-brain barrier because of its small molecular weight (24).

In the current study, the histopathological assessment of the brain tissues was performed at both light microscopic and ultrastructural levels. The brain morphology was normal in the control group, where as significant perivascular edema was observed in the trauma and vehicle groups. Intracellular edema is the first sign of cellular injury. Swelling, vacuolar changes, and lysis of some organelles are significant signs of acute cellular injury. In this study, the results of electron microscopic analysis also confirmed TBI related injury at cellular level. Furthermore, the intracellular edema and vacuoles that observed in the trauma and vehicle groups were observed to be decreased in the paeonol group.

Wu et al. (12) showed that paeonol could protect oxygenglucose-deprived hippocampal neurons by preventing excitotoxicity through NMDA receptors in cell culture. Zhong et al. (24) indicated that the neuroprotective effect of paeonol could be because of its free radical scavenging and antioxidant properties. It could additionally protect $\mathrm{Na}^{+} / \mathrm{K}^{+}$-ATPase activity and preserve energy metabolism (24). Recent studies conducted in cerebral ischemia animal models reported that paeonol pretreatment decreased cerebral edema and infarct volume besides preserving the blood-brain barrier and inhibiting microglial activation $(23,25)$. Zhao et al. (26) investigated the effects of paeonol treatment after cerebral ischemia and reported that paeonol suppresses microglial activation and astrocyte proliferation and exhibits a neuroprotective effect. In addition, Liao et al. (27) showed neuroprotective and antiinflammatory activities of paeonol in a cerebral ischemia and reperfusion model.

This study had some limitations. First, the use of paeonol as a pretreatment could decrease its practical application, particularly in emergency trauma situations. If results for inflammatory and other biochemical biomarkers, quantitative light and electron microscopy, and functional outcome scores had been obtained, the effects of paeonol could have been interpreted more mechanistically. Future studies using TBI animal models with an increased number of animals per group and different dosage regimens at different time periods can be conducted to understand the effectiveness of paeonol better. Furthermore, other TBI animal models (i.e., repetitive TBI models) can be studied.

\section{Conclusion}

This study is the first to evaluate the neuroprotective properties of paeonol in TBI. Paeonol has been shown to be effective in preventing neural damage secondary to TBI. After further experimental and clinical studies, paeonol may be approved for the TBI treatment.

\section{Ethics}

Ethics Committee Approval: Animal care and all experiments were conducted according tothe European Parliament and Council directive 2010/63/EU of September 22, 2010 with regard to the protection of animals for experimental use. Animal ethics committee permission is obtained from The Saki Yenilli Animal Care and Use Committee (0001.01.02). They reviewed and approved all experimental procedures used in this study.

Informed Consent: Due to the fact that this study is experiment study, informed consent was not obtained.

Peer-review: Internally and externally peer-reviewed.

\section{Authorship Contributions}

Concept: E.A., H.D., P.K.B., J.E., B.C.Y., Ç.T., Ç.Ö.Ö., L.G., B.G., Design: E.A., H.D., P.K.B., J.E., B.C.Y., Ç.T., Ç.Ö.Ö., L.G., B.G., Data Collection or Processing: E.A., H.D., P.K.B., J.E., B.C.Y., Ç.T., Ç.Ö.Ö., L.G., B.G., Analysis or Interpretation: E.A., H.D., P.K.B., J.E., B.C.Y., Ç.T., Ç.Ö.Ö., L.G., B.G., Literature Search: E.A., H.D., P.K.B., J.E., B.C.Y., Ç.T., Ç.Ö.Ö., L.G., B.G., Writing: P.K.B.

Conflict of Interest: No conflict of interest was declared by the authors.

Financial Disclosure: The authors declared that this study received no financial support. 


\section{References}

1. Acosta SA, Tajiri N, Shinozuka $K$, et al. Long-term upregulation of inflammation and suppression of cell proliferation in the brain of adult rats exposed to traumatic brain injury using the controlled cortical impact model. PLoS One. 2013;8:e53376.

2. Lozano D, Gonzales-Portillo GS, Acosta $S$, et al. Neuroinflammatory responses to traumatic brain injury: etiology, clinical consequences, and therapeutic opportunities. Neuropsychiatr Dis Treat. 2015;11:97-106.

3. Salehi $A$, Zhang $J H$, Obenaus A. Response of the cerebral vasculature following traumatic brain injury. J Cereb Blood Flow Metab. 2017;37:23202339.

4. Pop V, Badaut J. A neurovascular perspective for long-term changes after brain trauma. Transl Stroke Res. 2011;2:533-545.

5. Giacino JT, Whyte J, Bagiella E, et al. Placebo-controlled trial of amantadine for severe traumatic brain injury. N Engl J Med. 2012;366:819-826.

6. Kertmen $\mathrm{H}$, Gürer B, Yilmaz ER, et al. Antioxidant and antiapoptotic effects of darbepoetin- $\alpha$ against traumatic brain injury in rats. Arch Med Sci. 2015;11:1119-1128.

7. Özay R, Türkoğlu E, Gürer B, et al. Does Decorin Protect Neuronal Tissue via Its Antioxidant and Antiinflammatory Activity from Traumatic Brain Injury: An Experimental Study.World Neurosurg. 2017;97:407-415.

8. Paglia $D E$, Valentine $W N$. Studies on the quantitative and qualitative characterization of erythrocyte glutathione peroxidase. J Lab Clin Med. 1967;70:158-169.

9. Yilmaz $E R$, Kertmen $H$, Gürer $B$, et al. The protective effect of 2-mercaptoethane sulfonate (MESNA) against traumatic brain injury in rats. ActaNeurochir (Wien)2013;155:141-149; discussion 149

10. Perez-Polo JR, Rea HC, Johnson KM, et al. Inflammatory consequences in a rodent model of mild traumatic brain injury. J Neurotrauma. 2013;30:727740

11. Özay R, Türkoğlu ME, Gürer B, et al. The Protective Effect of Omeprazole Against Traumatic Brain Injury: An Experimental Study. World Neurosurg. 2017:104:634-643.

12. Wu JB, Song NN, Wei XB, et al. Protective effects of paeonol on cultured rat hippocampal neurons against oxygen-glucose deprivation-induced injury. J Neurol Sci. 2008;264:50-55.

13. Zhong $\mathrm{SZ}, \mathrm{Ge} \mathrm{QH}, \mathrm{Qu} \mathrm{R}$, et al. Paeonol attenuates neurotoxicity and ameliorates cognitive impairment induced by $d$-galactose in ICR mice. $J$ Neurol Sci. 2009; 277:58-64.
14. Jin $\mathrm{H}$, Wang $\mathrm{M}$, Wang J, et al. Paeonol attenuates isoflurane anesthesiainduced hippocampal neurotoxicity via modulation of JNK/ERK/P38MAPK pathway and regulates histone acetylation in neonatal rat. J Matern Fetal Neonatal Med. 2018;29:1-11.

15. Liu MH, Lin AH, Lee HF, et al. Paeonol attenuates cigarette smoke-induced lung inflammation by inhibiting ROS-sensitive inflammatory signaling. Mediators Inflamm. 2014;2014:651890.

16. Choy KW, Lau YS, Murugan D, et al. Chronic treatment with paeonol improves endothelial function in mice through inhibition of endoplasmic reticulum stress-mediated oxidative stress. PLoS One. 2017;12:e0178365.

17. Ding $Y, L i ~ Q, X u Y$, et al. Attenuating Oxidative Stress by Paeonol Protected against Acetaminophen-Induced Hepatotoxicity in Mice. PLoS One. 2016;11:e0154375.

18. Marmarou A, Foda MA, van den Brink W, et al. A new model of diffuse brain injury in rats. Part I: Pathophysiology and biomechanics. J Neurosurg. 1994;80:291-300.

19. Ucar T, Tanriover G, Gurer I, et al. Modified experimental mild traumatic brain injury model. J Trauma. 2006;60:558-565.

20. Maas AIR, Menon DK, Adelson PD, et al. Traumatic brain injury: integrated approaches to improve prevention, clinical care, and research. Lancet Neurol. 2017; 16:987-1048.

21. Yasuda $T$, Kon $R$, Nakazawa $T$, et al. Metabolism of paeonol in rats. J Nat Prod. 1999; 62:1142-1144.

22. Ma $L Y, X u X D$, Zhang Q, et al. Paeonol pharmacokinetics in the rat following i.m. administration. Eur J Drug MetabPharmacokinet. 2008;33:133-136.

23. Zhao $Y, F u$, Zhang $X$, et al. Paeonol pretreatment attenuates cerebral ischemic injury via upregulating expression of pAkt, Nrf2, HO-1 and ameliorating BBB permeability in mice. Brain Res Bull. 2014; 109:61-67.

24. Zhong $\mathrm{SZ}, \mathrm{Ge} \mathrm{QH}, \mathrm{Qu} \mathrm{R}$, et al. Paeonol attenuates neurotoxicity and ameliorates cognitive impairment induced by $d$-galactose in ICR mice. J Neurol Sci. 2009; 277:58-64.

25. Hsieh $\mathrm{CL}$, Cheng $\mathrm{CY}$, Tsai $\mathrm{TH}$, et al. Paeonol reduced cerebral infarction involving the superoxide anion and microglia activation in ischemiareperfusion injured rats. J Ethnopharmacol. 2006;106:208-215.

26. Zhao B, Shi OJ, Zhang ZZ, et al. Protective effects of paeonol on subacute/ chronic brain injury during cerebral ischemia in rats. ExpTher Med. 2018;15:3836-3846

27. Liao WY, Tsai TH, Ho TY, et al. Neuroprotective Effect of Paeonol Mediates Anti-Inflammation via Suppressing Toll-Like Receptor 2 and Toll-Like Receptor 4 Signaling Pathways in Cerebral Ischemia-Reperfusion Injured Rats. Evid Based Complement Alternat Med. 2016;2016:3704647. 